JPP IPTEK Mei 2019, Vol. 3, No. 1

ISSN 2620-7745 (online)

https://dx.doi.org/10.31284/j.jpp-iptek.2019.v3i1.458

\title{
Penataan Administrasi Data Siswa Taman Pendidikan Al-Qur'an An-Nida Menggunakan Teknologi Informasi dan Komunikasi
}

\author{
Priza Pandunata ${ }^{1}$, Oktalia Juwita $^{2}$, Aryo Prakoso $^{3}$ \\ Universitas Jember \\ priza@unej.ac.id
}

\begin{abstract}
Taman Pendidikan Al-Qur'an (TPA) An-Nida is located in the village area of Dukuhdempok, Wuluhan Sub-district, Jember. The exact address is on Jl. Moch. Serueji No. 18 B, Wuluhan. TPA An-Nida site is located at $32 \mathrm{~km}$ from Jember University. The management of TPA An-Nida and their services are still conventional. This causes difficulties when searching for students data. The data duplication will also possible. Besides that, TPA An-Nida still does not have the facilities and infrastructure of information and communication technology (ICT). Even though this ICT can be used to improve TPA services and management and can be used as a means of ICT-based learning for the students. Based on these problems, in the Program Pengabdian Pemula (PPP), this database application was made to accommodate the student's administrative data, attendance data and student's achievements, documentation of TPA activities and the teacher data. Procurement of ICT tools in the form of tablet PCs to improve TPA services and management and be used as learning media for the students. Training on the use of the student's database application. The results of the PPP activities are (1) Improving the management of TPA An-Nida services with the student's database application that is centralizing student's data storage, data on student's achievements, and TPA instructors' data, (2) Digitizing documentation of TPA activities neatly arranged in the form of TPA An-Nida portfolio, (3) Managing TPA and learning process using ICT, (4) Writing a scientific articles in national journal, and (5) Videotaping the PPP activities.
\end{abstract}

Keywords: Application, Database, Centralized data, Tablet PC, Information and communication technology

\begin{abstract}
ABSTRAK
Taman Pendidikan Al-Qur'an (TPA) An-Nida berada di wilayah Desa Dukuhdempok, Kecamatan Wuluhan, Kabupaten Jember. Alamat tepatnya berada di Jl. Moch. Serueji No. 18 B, Wuluhan. Lokasi TPA An-Nida berada sejauh $32 \mathrm{~km}$ dari Universitas Jember. Di era digital saat ini, manajemen dan layanan TPA An-Nida masih konvensional. Di antaranya adalah pencatatan data santri, presensi, dan prestasi santri yang masih dikelola secara manual. Hal ini menyulitkan saat pencarian data santri. Terjadinya duplikasi data santri juga memungkinkan. Selain itu, TPA An-Nida masih belum memiliki sarana dan prasarana teknologi informasi dan komunikasi (TIK). Padahal, TIK ini bisa dimanfaatkan untuk meningkatkan layanan dan manajemen TPA serta dapat digunakan sebagai sarana pembelajaran berbasis TIK bagi santri. Berdasarkan permasalahan tersebut, pada Progran Pengabdian Pemula (PPP) ini, dilakukan pembuatan aplikasi database untuk menampung data administrasi santri, data presensi dan prestasi santri, dokumentasi kegiatan TPA, serta data pengajar TPA. Pengadaan alat TIK berupa PC tablet untuk meningkatkan layanan dan manajemen TPA serta digunakan sebagai media pembelajaran bagi santri. Pelatihan pemakaian aplikasi database santri serta aplikasi media belajar santri berbasis TIK. Hasil dari kegiatan PPP ini adalah (1) Meningkatkan layanan pengelolaan TPA An-Nida dengan adanya aplikasi database santri yang terpusat untuk penyimpanan data santri, data keluar/masuk santri, prestasi santri, serta pengajar TPA, (2) Mendigitalkan dokumentasi kegiatan TPA yang tersusun rapi berupa portofolio TPA An-Nida. (3) Mengelola TPA dan pembelajaran menggunakan TIK, (4) Menulis artikel ilmiah dalam jurnal nasional, serta (5) Mendokumentasikan kegiatan PPP dalam bentuk video.
\end{abstract}

Kata kunci: Aplikasi, Basis data, Data terpusat, PC tablet, Teknologi informasi dan komunikasi

\section{PENDAHULUAN}

Taman Pendidikan Al-Qur'an (TPA) bertujuan menyiapkan terbentuknya generasi qur'ani, yaitu generasi yang memiliki komitmen terhadap al-Qur'an sebagai sumber perilaku, pijakan hidup, dan rujukan segala urusannya (Hidayat, 2011). Hal ini ditandai dengan kecintaan yang mendalam terhadap Al-Qur'an, kemampuan dan kerajinan dalam membacanya, keberlanjutan 
dalam mempelajari isi kandungannya, dan kemauan yang kuat untuk mengamalkannya secara kafah dalam kehidupan sehari-hari. Hal tersebut juga selaras dengan Undang-undang RI No. 2 Tahun 1989 tentang Sistem Pendidikan Nasional, Bab II Pasal 4, yang menegaskan bahwa salah satu ciri manusia Indonesia yang menjadi tujuan pendidikan nasional adalah "manusia yang beriman dan bertakwa" (Rodahad, Khakim, Afandi, Utomo, \& Rahman, 2015).

TPA merupakan lembaga pendidikan nonformal yang dikelola secara mandiri oleh masyarakat. TPA memberikan pendidikan agama Islam pada umumnya dan mengajarkan baca tulis Al-Qur'an secara khusus (Usman, 2015). Sasaran dari TPA adalah masyarakat umum, baik dewasa maupun anak-anak. Akan tetapi, biasanya yang mengikuti kegiatan pendidikan di TPA mayoritas adalah anak-anak (Muntoha, Jamroni, \& Jabbar, 2015).

Kegiatan belajar mengajarnya pun fleksibel sesuai dengan situasi dan kondisi masingmasing pengelola TPA. Keberadaan TPA merupakan penunjang pendidikan agama pada lembaga pendidikan formal (TK, SD, MI) (Muhajirin \& Ratnawati, 2016). Untuk itu, TPA diselenggarakan pada siang/sore hari yang tidak bersamaan dengan jam sekolah (pendidikan formal).

An-Nida merupakan TPA yang berada di wilayah Desa Dukuhdempok, Kecamatan Wuluhan, Kabupaten Jember. Alamat tepatnya ada di Jl. Moch. Serueji No. 18 B, Wuluhan. TPA An-Nida dikelola oleh Pimpinan Ranting Aisyiyah Wuluhan. Gedung dan sarana prasarana yang digunakan untuk kegiatan belajar mengajar menggunakan gedung TK Aisyiyah. TPA An-Nida ini melaksanakan kegiatan pendidikan baca tulis Al-Qur'an bagi anak-anak di wilayah sekitar desa Dukuhdempok. Saat ini, jumlah santri yang aktif ada 40 orang. Sementara jumlah tenaga pengajar ada 4 orang.

Berdasarkan hasil analisis situasi di TPA An-Nida, permasalahan yang menjadi prioritas dan perlu untuk diselesaikan melalui program Progran Pengabdian Pemula (PPP) ini antara lain data santri dicacat secara manual, risiko penyimpanan data secara manual lebih tinggi (kesulitan saat pencarian, duplikasi data, rawan kebakaran, dan rayap), dokumentasi kegiatan TPA belum tertata dengan rapi, sarana dan prasarana TIK yang terbatas, data prestasi belajar santri dikelola secara manual, dan belum adanya database pengajar TPA.

Solusi yang ditawarkan untuk menyelesaikan permasalahan tersebut adalah membangun aplikasi database santri yang terpusat untuk penyimpanan data santri, data keluar/masuk santri, prestasi santri, pengajar TPA, serta pengelolaan dan pembelajaran TPA menggunakan TIK. Solusi tersebut diberikan guna meningkatkan layanan pengelolaan TPA An-Nida.

\section{METODE PELAKSANAAN}

Berdasarkan beberapa permasalahan yang sedang dihadapi oleh mitra, melalui Program Pengabdian Pemula (PPP) ini dilakukan beberapa langkah solusi untuk mengatasi permasalahan yang telah disebutkan.

\subsection{Metode Pendekatan}

Beberapa metode pendekatan solusi yang ditawarkan untuk menyelesaikan permasalahan mitra, TPA An-Nida, adalah seperti ditunjukkan pada Tabel 1.

Tabel 1. Solusi yang Ditawarkan melalui PPP

\begin{tabular}{cll}
\hline No. & Permasalahan & Solusi \\
\hline 1 & Data santri dicacat secara manual & Pembuatan database santri terpusat \\
2 & $\begin{array}{l}\text { Risiko penyimpanan data secara manual } \\
\text { lebih tinggi (kesulitan saat pencarian, } \\
\text { duplikasi data, rawan kebakaran, dan rayap) }\end{array}$ & $\begin{array}{l}\text { Penyimpanan dan backup data } \\
\text { menggunakan TIK }\end{array}$ \\
3 & $\begin{array}{l}\text { Dokumentasi kegiatan TPA belum tertata } \\
\text { dengan rapi }\end{array}$ & Pembuatan database kegiatan TPA \\
\hline
\end{tabular}




\begin{tabular}{cll}
\hline No. & Permasalahan & Solusi \\
\hline 4 & Sarana dan prasarana TIK yang terbatas & $\begin{array}{l}\text { Penyediaan komputer personal (PC) bagi } \\
\text { TPA An-Nida }\end{array}$ \\
5 & $\begin{array}{l}\text { Data prestasi belajar santri dikelola secara } \\
\text { manual }\end{array}$ & Pembuatan database prestasi santri \\
6 & Belum ada database pengajar TPA & Pembuatan database tenaga pengajar \\
\hline
\end{tabular}

\subsection{Prosedur Kerja}

Dari seluruh metode pendekatan untuk solusi yang ditawarkan, selanjutnya disusun prosedur kerja untuk merealisasikan metode yang ditawarkan. Beberapa prosedur kerja yang telah dirancang sebagaimana ditunjukkan oleh Tabel 2.

Tabel 2. Program Kerja PPP

\begin{tabular}{|c|c|c|c|}
\hline No. & Permasalahan & Solusi & Program Kerja \\
\hline 1 & $\begin{array}{l}\text { Data santri dicacat } \\
\text { secara manual }\end{array}$ & $\begin{array}{l}\text { Pembuatan database } \\
\text { santri terpusat }\end{array}$ & $\begin{array}{l}\text { Pembuatan aplikasi database santri } \\
\text { yang terdiri atas data santri dan data } \\
\text { masuk/keluar santri. } \\
\text { - Uji coba aplikasi. } \\
\text { - Pembuatan buku manual penggunaan } \\
\text { aplikasi. }\end{array}$ \\
\hline 2 & $\begin{array}{l}\text { Risiko penyimpanan } \\
\text { data secara manual } \\
\text { lebih tinggi (kesulitan } \\
\text { saat pencarian, } \\
\text { duplikasi data, rawan } \\
\text { kebakaran, dan rayap) }\end{array}$ & $\begin{array}{l}\text { Penyimpanan dan } \\
\text { backup data } \\
\text { menggunakan TIK }\end{array}$ & $\begin{array}{l}\text { Pembuatan fasilitas untuk menyimpan } \\
\text { dan mem-backup database santri. }\end{array}$ \\
\hline 3 & $\begin{array}{l}\text { Dokumentasi kegiatan } \\
\text { TPA belum tertata } \\
\text { dengan rapi }\end{array}$ & $\begin{array}{l}\text { Pembuatan database } \\
\text { kegiatan TPA }\end{array}$ & $\begin{array}{l}\text { - Pembuatan aplikasi database kegiatan } \\
\text { TPA. } \\
\text { - Uji coba aplikasi. } \\
\text { - Pembuatan buku manual penggunaan } \\
\text { aplikasi. }\end{array}$ \\
\hline 4 & $\begin{array}{l}\text { Sarana dan prasarana } \\
\text { TIK yang terbatas }\end{array}$ & $\begin{array}{l}\text { Penyediaan komputer } \\
\text { personal (PC) bagi } \\
\text { TPA An-Nida }\end{array}$ & $\begin{array}{l}\text { - Pengadaan komputer personal (PC } \\
\text { tablet). } \\
\text { - Instalasi aplikasi database. } \\
\text { - Tutorial pemakaian aplikasi database. } \\
\text { - Instalasi aplikasi pembelajaran untuk } \\
\text { santri. } \\
\text { - Tutorial pemakaian aplikasi } \\
\text { pembelajaran untuk santri. }\end{array}$ \\
\hline 5 & $\begin{array}{l}\text { Data prestasi belajar } \\
\text { santri dikelola secara } \\
\text { manual }\end{array}$ & $\begin{array}{l}\text { Pembuatan database } \\
\text { prestasi santri }\end{array}$ & $\begin{array}{l}\text { Pembuatan aplikasi database prestasi } \\
\text { dan presensi santri. } \\
\text { - Uji coba aplikasi. } \\
\text { - Pembuatan buku manual penggunaan } \\
\text { aplikasi. }\end{array}$ \\
\hline 6 & $\begin{array}{l}\text { Belum ada database } \\
\text { pengajar TPA }\end{array}$ & $\begin{array}{l}\text { Pembuatan database } \\
\text { tenaga pengajar }\end{array}$ & $\begin{array}{l}\text { - Pembuatan aplikasi database } \\
\text { pengajar. } \\
\text { - Uji coba aplikasi. } \\
\text { - Pembuatan buku manual penggunaan } \\
\text { aplikasi. }\end{array}$ \\
\hline
\end{tabular}


Berdasarkan program kerja PPP yang terdapat pada Tabel 2, tim pengusul mendefinisikan indikator capaian kinerja (performance indicator) dan output masing-masing agar tingkat ketercapaian setiap butir program kerja dapat terukur dengan baik. Tabel 3 berikut menyajikan pemetaan antara program kerja, indikator capaian kinerja, dan output-nya.

Tabel 3. Indikator Capaian Kinerja dan Output dari Program Kerja

\begin{tabular}{|c|c|c|c|}
\hline No. & Program Kerja & Indikator Capaian Kerja & Output \\
\hline 1 & $\begin{array}{l}\text { Pembuatan aplikasi database } \\
\text { santri yang terdiri atas data } \\
\text { santri dan data masuk/keluar } \\
\text { santri. } \\
\text { - Uji coba aplikasi. } \\
\text { - Pembuatan buku manual } \\
\text { penggunaan aplikasi. }\end{array}$ & $\begin{array}{l}\text { - Aplikasi database } \\
\text { santri } \\
\text { - Dokumen evaluasi } \\
\text { aplikasi database } \\
\text { - Dokumen manual } \\
\text { pemakaian aplikasi }\end{array}$ & $\begin{array}{l}\text { Aplikasi database } \\
\text { santri. }\end{array}$ \\
\hline 2 & $\begin{array}{l}\text { Pembuatan fasilitas untuk } \\
\text { menyimpan dan mem-backup } \\
\text { database santri. }\end{array}$ & $\begin{array}{l}\text { Ada menu pada aplikasi } \\
\text { untuk melakukan } \\
\text { penyimpanan dan backup } \\
\text { database }\end{array}$ & $\begin{array}{l}\text { Penyimpanan dan backup } \\
\text { database pada server }\end{array}$ \\
\hline 3 & $\begin{array}{l}\text { - Pembuatan aplikasi database } \\
\text { kegiatan TPA. } \\
\text { - Uji coba aplikasi. } \\
\text { - Pembuatan buku manual } \\
\text { penggunaan aplikasi. }\end{array}$ & $\begin{array}{l}\text { - Aplikasi database } \\
\text { kegiatan TPA } \\
\text { - Evaluasi aplikasi } \\
\text { database } \\
\text { - Dokumen manual } \\
\text { pemakaian aplikasi } \\
\end{array}$ & $\begin{array}{l}\text { Aplikasi database } \\
\text { kegiatan TPA }\end{array}$ \\
\hline 4 & $\begin{array}{l}\text { Pengadaan komputer personal } \\
\text { (PC tablet). } \\
\text { - Instalasi aplikasi database. } \\
\text { - Tutorial pemakaian aplikasi } \\
\text { database. } \\
\text { - Instalasi aplikasi pembelajaran } \\
\text { untuk santri. } \\
\text { - Tutorial pemakaian aplikasi } \\
\text { pembelajaran untuk santri. }\end{array}$ & $\begin{array}{l}\text { - Pembelian PC tablet } \\
\text { - Setting PC tablet serta } \\
\text { instalasi aplikasi } \\
\text { database } \\
\text { - Workshop penggunaan } \\
\text { aplikasi } \\
\text { - Mengumpulkan } \\
\text { aplikasi pembelajaran } \\
\text { Al-Qur'an yang sesuai } \\
\text { dengan kurikulum TPA } \\
\text { dari Google Play serta } \\
\text { menginstal pada PC } \\
\text { tablet } \\
\text { - Workshop penggunaan } \\
\text { aplikasi } \\
\end{array}$ & $\begin{array}{l}\text { Ada komputer personal } \\
\text { (PC tablet) }\end{array}$ \\
\hline 5 & $\begin{array}{l}\text { - Pembuatan aplikasi database } \\
\text { prestasi dan presensi santri. } \\
\text { - } \quad \text { Uji coba aplikasi. } \\
\text { - Pembuatan buku manual } \\
\text { penggunaan aplikasi. }\end{array}$ & $\begin{array}{l}\text { - Aplikasi database } \\
\text { prestasi dan presensi } \\
\text { - Evaluasi aplikasi } \\
\text { database } \\
\text { - Dokumen manual } \\
\text { pemakaian aplikasi } \\
\end{array}$ & $\begin{array}{l}\text { Aplikasi database } \\
\text { prestasi santri }\end{array}$ \\
\hline 6 & $\begin{array}{l}\text { - Pembuatan aplikasi database } \\
\text { pengajar. } \\
\text { - } \quad \text { Uji coba aplikasi. } \\
\text { - Pembuatan buku manual } \\
\text { penggunaan aplikasi. }\end{array}$ & $\begin{array}{l}\text { - Aplikasi database } \\
\text { pengajar } \\
\text { - Evaluasi aplikasi } \\
\text { database } \\
\text { - Dokumen manual } \\
\text { pemakaian aplikasi } \\
\end{array}$ & $\begin{array}{l}\text { Aplikasi database } \\
\text { pengajar TPA }\end{array}$ \\
\hline
\end{tabular}


Adapun pembuatan aplikasi database untuk TPA An-Nida yang meliputi database santri, database kegiatan TPA, database prestasi dan presensi santri, serta database tenaga pengajar dilakukan dengan tahapan berikut.

1) Tahap identifikasi kebutuhan pengguna aplikasi, meliputi:

a. Mengumpulkan informasi dari berbagai sumber

b. Melakukan wawancara dengan pengguna aplikasi yaitu TPA An-Nida

2) Tahap analisis dan desain aplikasi, meliputi:

a. Melakukan analisis sistem yang sedang berjalan saat ini

b. Merancang sistem yang akan dibangun, meliputi:

i. Perancangan arsitektur aplikasi

ii. Perancangan data

iii. Perancangan interface (antarmuka) aplikasi

3) Tahap implementasi pembuatan aplikasi, meliputi:

a. Membuat database santri

b. Menyiapkan server penyimpanan data

c. Membuat aplikasi database administrasi santri

4) Tahap uji coba dan evaluasi, meliputi:

a. Menguji jalannya aplikasi yang telah dibuat

b. Melakukan debugging kesalahan yang terjadi

5) Tahap dokumentasi aplikasi, meliputi:

a. Membuat dokumentasi sistem yang telah dibangun

b. Membuat buku manual penggunaan sistem

6) Tahap serah terima aplikasi, meliputi:

a. Serah terima aplikasi database admnnintrasi santri

b. Pelatihan pemakaian dan pengoperasian aplikasi

7) Tahap pendampingan dan monitoring

\section{HASIL DAN PEMBAHASAN}

Metode pelaksanaan yang dilakukan sesuai dengan uraian pada bab 2. Penerapan TIK yang telah dilakukan antara lain:

1. Penyusunan manual instalasi dan manual penggunaan Aplikasi

2. Pengelolaan data santri/murid TPA An-Nida

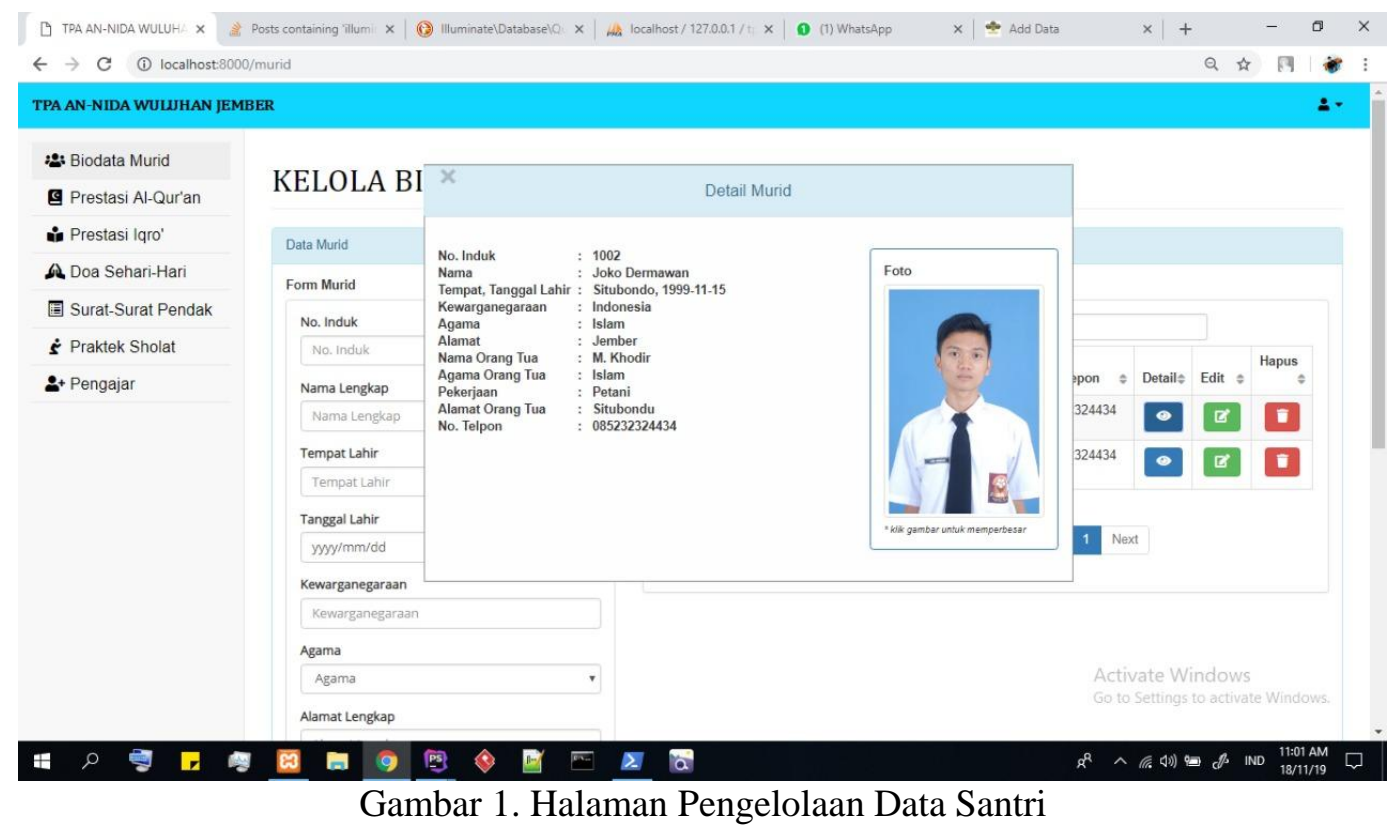


3. Pengelolaan data Prestasi Iqro' Santri

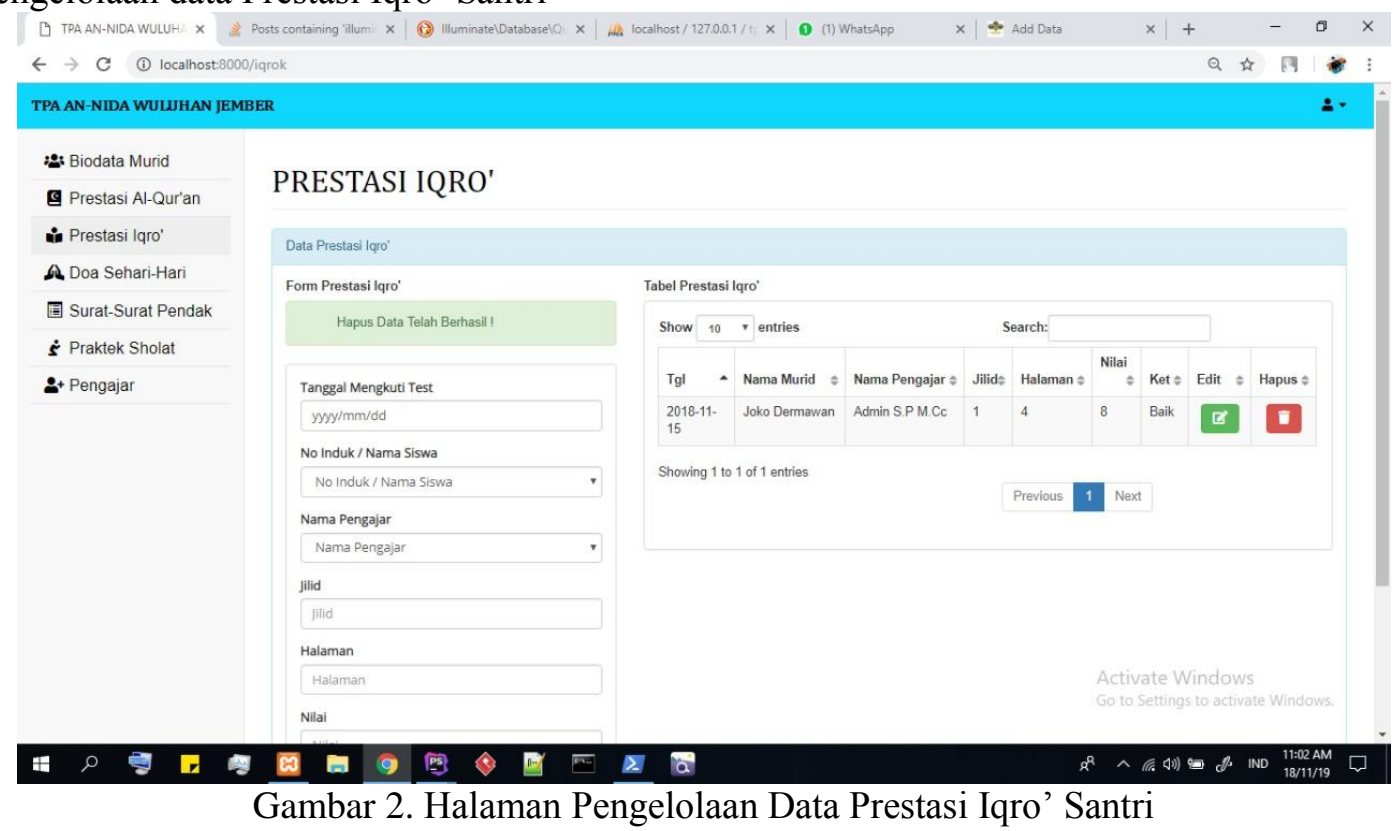

4. Pengelolaan data prestasi Al-Qur'an Santri

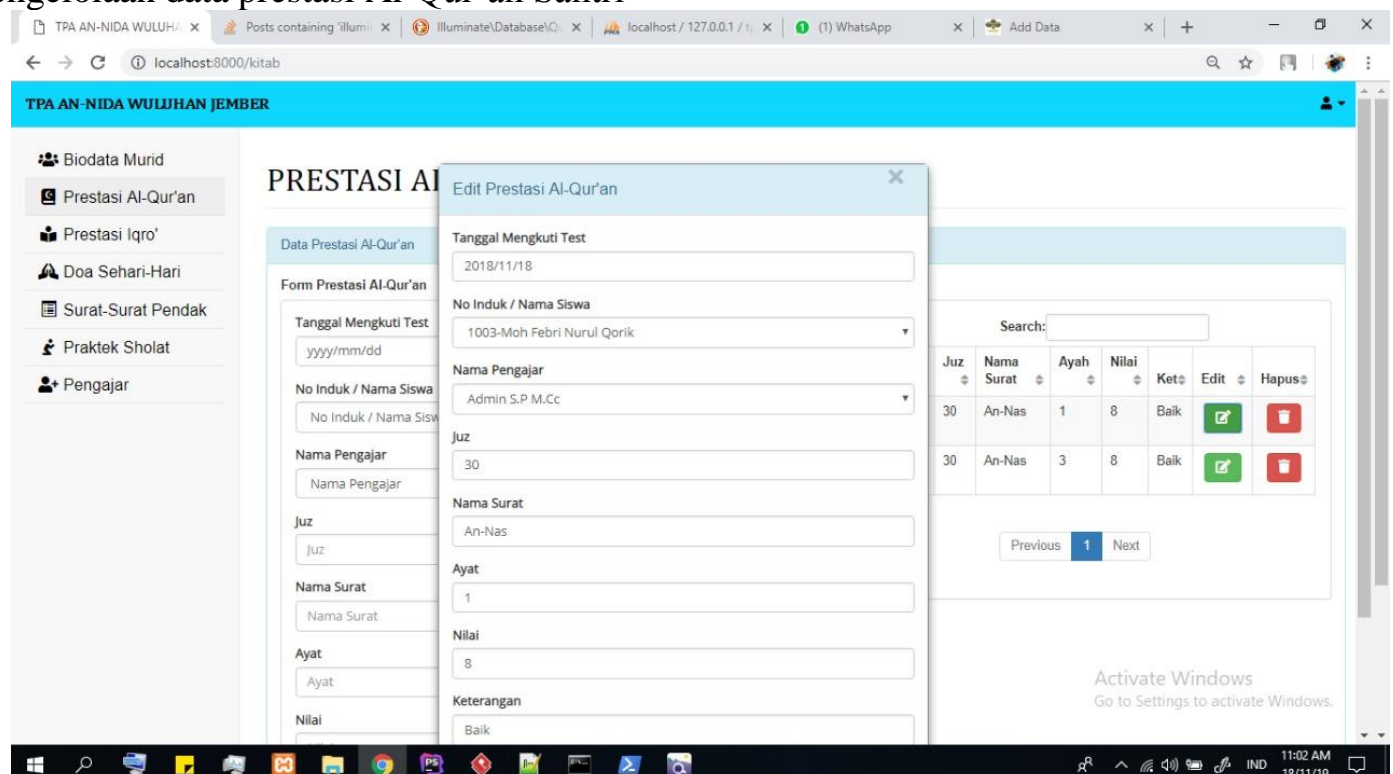

Gambar 3. Halaman Pengelolaan Data Prestasi Al-Qur'an Santri 
5. Pengelolaan data Pengajar TPA

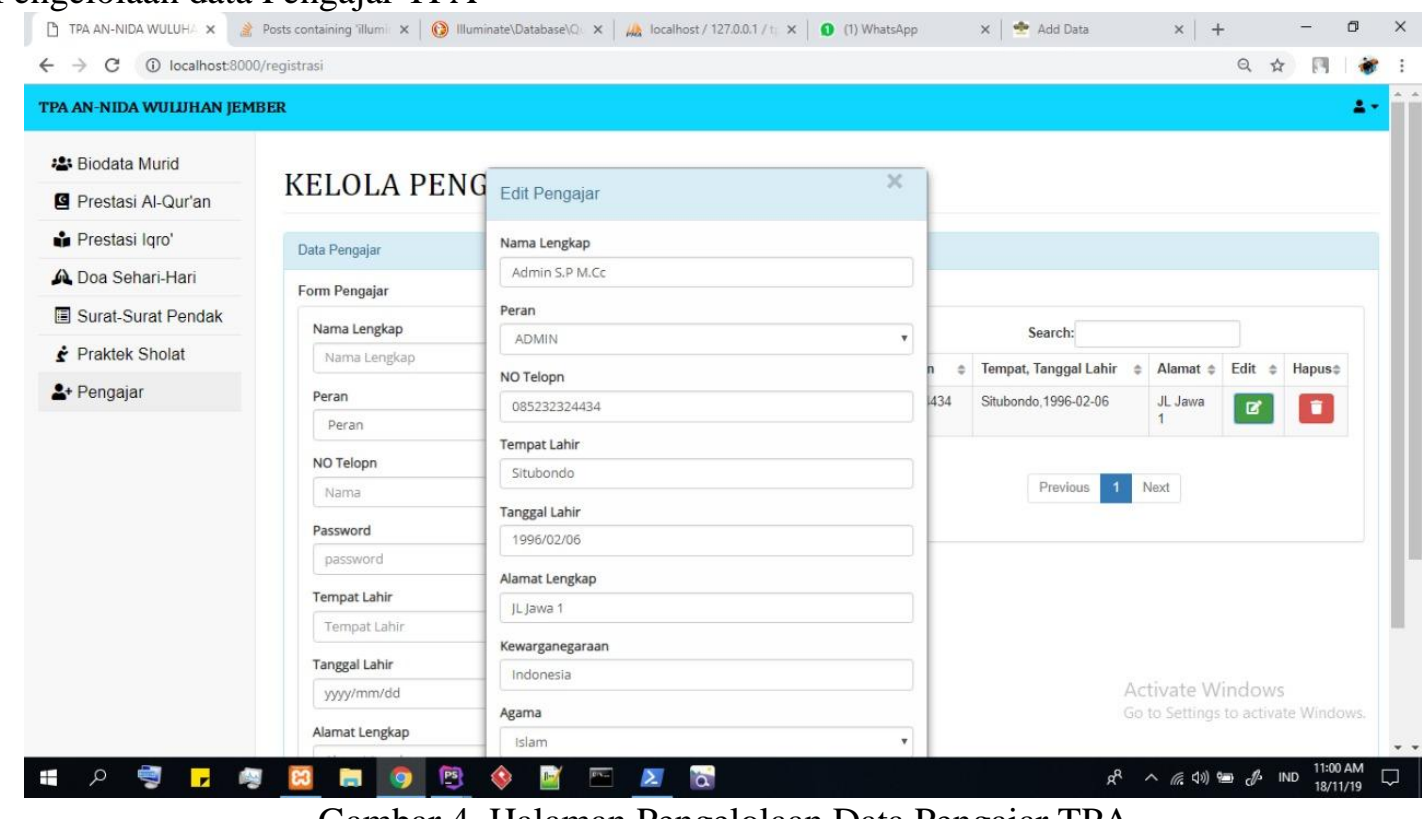

Gambar 4. Halaman Pengelolaan Data Pengajar TPA

6. Halaman Log In Aplikasi

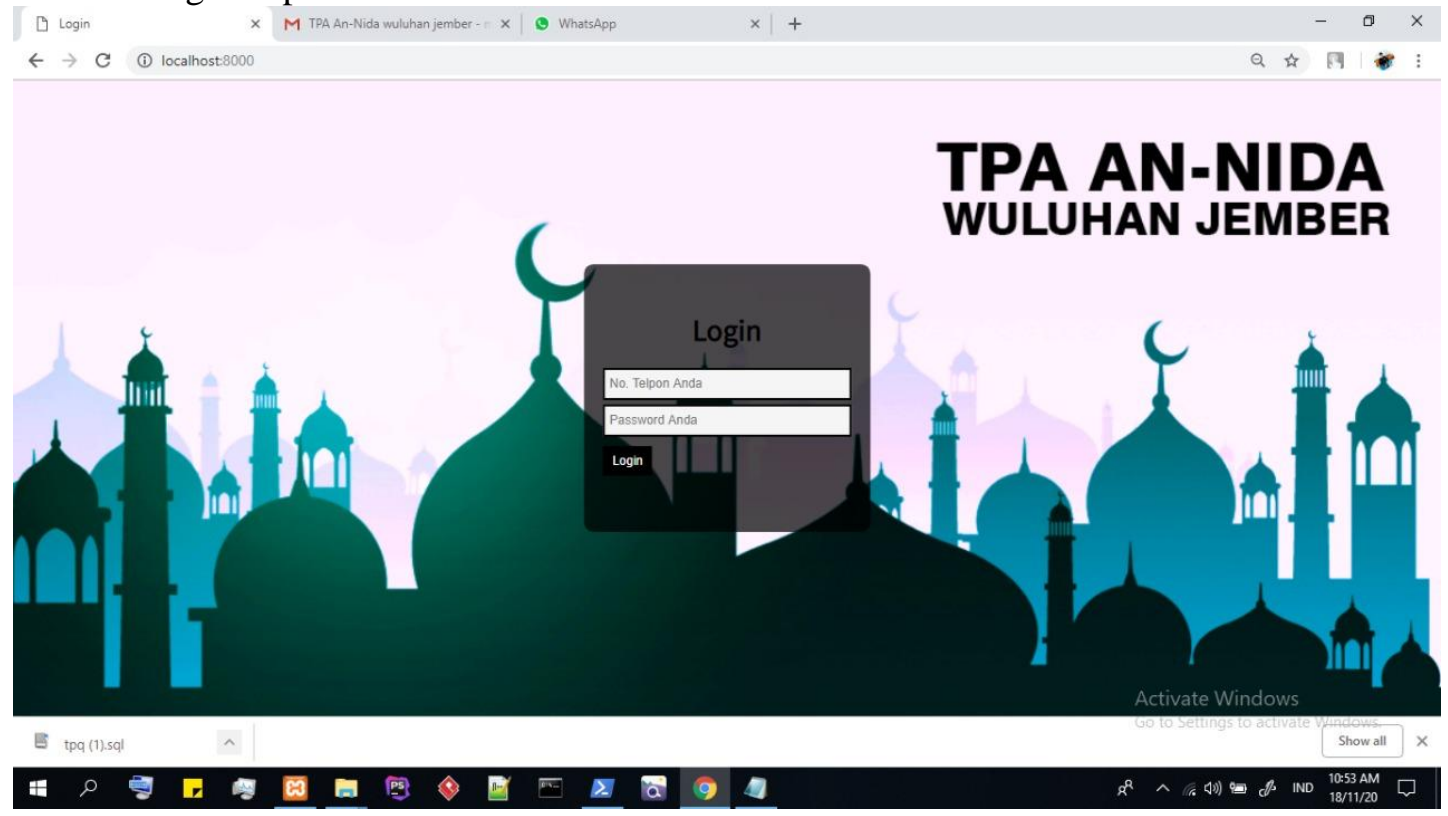

Gambar 5. Halaman Log In Aplikasi

Manfaat dari kegiatan pengabdian kepada masyarakat ini antara lain:

1) Data santri tercatat secara digital

2) Risiko pada penyimpanan data dapat menjadi lebih rendah

3) Dokumentasi kegiatan TPA dapat tertata lebih rapi

4) Data prestasi belajar santri dapat tersimpan secara digital

5) Terdapat database pengajar TPA 


\section{UCAPAN TERIMA KASIH}

Terimakasih atas bantuan dana Dirjen Riset dan Pengabdian Masyarakat (DRPM) serta Universitas Jember sehingga kegiatan pengabdian kepada masyarakat ini dapat terselenggara. Terima kasih juga kepada Taman Pendidikan Al-Qur'an An-Nida Wuluhan khususnya para pengelola TPA dan Ibu Sholeha selaku Ketua TPA An-Nida di Desa Wuluhan, Kabupaten Jember, Jawa Timur atas kerja sama dan bantuannya dalam pelaksanaan kegiatan ini.

\section{DAFTAR PUSTAKA}

Hidayat, A. (2017). Sistem Informasi Akademik Taman Pendidikan Al-Qur'an (TPA) pada AlMukaramah Bandung. 1-20.

Muhajirin, Ratnawati, 2016. Pemanfaatan Aplikasi Berbasis Teknologi Iinformsi Dan Komunikasi Pada Taman Pengajian Al-Qur'an Nurul Muhammad Dan Miftahul Khair. Jurnal Inspiraton, Volume 6, Nomor 2, Hal. 165-172.

Muhajirin, \& Ratnawati. (2016). Pemanfaatan Aplikasi Berbasis Teknologi Informasi dan Komunikasi pada Taman Pengajian Al-Qur'an Nurul Muhammad dan Miftahul Khair. Jurnal Inspiration, 6(2), 165-172.

Muntoha, Jamroni, \& Jabbar, A. A. (2015). Pemanduan Manajemen Taman Pendidikan Al-Qur'an (TPA) di Masjid Arofah, Dusun Bandung dan Dusun Songbanyu 1, Kecamatan Songbanyu, Gunung Kidul, Daerah Istimewa Yogyakarta. Jurnal Inovasi dan Kewirausahaan, 4(3), $155-160$.

Rodahad, A., Khakim, A. K., Afandi, A., Utomo, B. A., \& Rahman, K. N. (2015). Sistem Informasi Pengelolaan Data TKA, TPA Badko Kabupaten Bantul Berbasis Framework Codeigniter. Diambil dari http://jurnal.stmikelrahma.ac.id/assets/file/Anin\%20Rodahad,\%20Anis \%20Khoirul\%20Khakim,\%20Arif\%20Afandi,\%20Bayu\%20Ari\%20Utomo,\%20Kholid $\% 20$ Nur\%20Rahman_stmikelrahma.pdf

Usman. (2015). Implementasi Kebijakan Kementerian Agama Terhadap Penyelenggaraan Taman Pendidikan Al-Qur'an di Kabupaten Pasuruan. Adabiyah: Jurnal Pendidikan Islam, 1(1), 63-80. 